\author{
NABA KUMAR ADAK \\ Sabang Sajanikanta Mahavidyalaya, India
}

\title{
AUSTRIAN SCHOOL OF ECONOMICS' PRESCRIPTIONS FOR MONETARY REFORMS WILL CAUSE COMPLETE CHAOS IN THE ECONOMY AND RUIN THE ECONOMIC SYSTEM
}

\begin{abstract}
:
The purpose of this paper is to show how the Austrian School of Economics' suggestions and prescriptions can cause complete chaos and anarchy in the economic system. The Austrian School of Economics' diagnosis of the defects in the functioning and practice of economics are more or less as the following. It thinks that the creation of money out of thin air and lowering interest rate for lending that money are the primary causes of inflation and boom-bust cycle, both of which are detrimental to the economy. Besides, this School's opinion is that the government in connivance with the central bank adopts such policies like bailing out and spending excessively. It increases the government debt unnecessarily. To repay this debt, the government increases tax which in turn reduces the spending capacity of the tax-payers. Thus, according to this School, both the monetary policy of the central bank and the fiscal policy of the government (government intervention in the economics and financial system) cause unnatural and harmful effects on the overall economic condition of a nation.

To ameliorate these defects, the Austrian School of Economics prescribes the following remedies. This School thinks, as money is not anchored to any commodity, so the central bank and government are in a position to increase the money supply without limit; this increase in money supply causes inflation which in turn leads to more demand for money supply. To meet this new demand for money the central bank creates and supplies more amount of money and lower the interest rate than the natural rate of interest. This increase in money-supply, again, causes inflation and renewed demand for extra money; again extra supply of money, again inflation increases. Thus the vicious circle of money supply and inflation leads to boom and bust. Therefore, this School suggests that money-creation should be anchored to some commodity so that creation of money cannot be unlimited. This School thinks that if money-creation is based on the standard of gold and silver then there will be no fiat money or easy money and inflation will be controlled and there will be little chance of occurring boom-bust cycle.

There other suggestion is that the central bank should be dissolved or abolished and there should not be any central authority to impose any uniform monetary policy on the economy. In every area there will be banks independent of any superior authority; the monetary policy and the interest rates will be formulated by the market forces of the concerned area where the authority of a bank will be operative. This School prescribes unfettered market system. This School also suggests that government should not interfere into the economic and financial activities neither in the positive way like bailing out any falling bank or corporate nor by enforcing any law that may control the economy in any way. This School also suggests that government should minimize its expenditure even by curtailing its spending for what is considered as public works. This School is also of the opinion that government should lower its tax-rate or abolish tax altogether.

According to the Austrian School of Economics, in the present economics system, the central bank creates fiat money or debt money to give loans and thus increases the supply of money. The
\end{abstract}


Austrian School suggests that if money creation is followed strictly with the commodity (gold) standard then loan can be given only by using the savings and there will be no possibility of increase in the money-supply as existing money that is saved will be used for lending purposes. Therefore, no question of inflation due to increase in money-supply (fiat money that is created out of nothing) will arise.

It will be simply impossible to deal with all the prescriptions and suggestions of the Austrian School in this paper and to suggest how those prescriptions may be developed further so as to make them function flawless or more correctly. It also becomes imperative to explain in which way the diagnosis and prescriptions of other Schools are wrong. It seems me that the differences of opinion among these Schools are mostly due to the absence of any universally accepted definition and function of money and how money should be oriented to suit our purpose of achieving a sustainable economic growth unhampered by occasional visit of boom-bust cycles.

Therefore, the purpose of this paper is to suggest that while it is correct that money should be anchored to commodity, yet more thoughts are necessary as to how the growing demand for money with the expanding monetary activities could be met. If we can arrive at a correct definition of money and how we can orient the money to function in the way to eliminate those harmful effects that, the Austrian School of Economics has shown, occur in the present economic system. Therefore, primary aim of this paper is to examine how far the assertion that money must be any commodity is workable in the economic and financial systems of a country.

\section{Keywords:}

Natural rate of interest, commodity money, fiat money, boom-bust cycle, government intervention in financial matters, inflation, free market 


\section{Introduction}

There are several contesting schools that explain the economics, find problems in the functioning in economics and in monetary and fiscal policies, and prescribe sustainable solutions to the economics problems. One of these schools is the Austrian School of Economics that claims that its diagnosis of the defects of economics and its prescriptions for solutions of those defects are more correct than those of other Schools of Economics. However, all other Schools of Economics like Chicago School of Economics, PostKeynesian School of Economics, Modern Monetary Theorists etc also claim that their diagnosis and prescriptions are correct. Now, it is to be noted that opinions of these schools are often different and contradictory and that though each School is very well acquainted with the claims of other Schools, yet each school refutes others' view points.

The Austrian School has identified many characteristics of money and monetary policy as they are practiced and functioning nowadays. They deal with money embezzlement and fraudulent money creation by the banks. They view that the fractional reserve banking by the banks and creation of fiat money by the central bank and the government intervention in the monetary policy are the real causes of boom-bust cycles. They also of the view that central bank's control of money supply and the lowering of interest rate causes destabilization of the financial and economic system of a country. They suggest some remedies to get out of these defects. They advocates free market policy unhampered by the authoritative policies of the central bank. They favor natural interest rate. They suggest dissolution of the central bank and elimination of any type of government control on finance and economics. To achieve these ends, they prescribe that introduction of commodity money will solve these problems including the boom-bust cycle. They also suggest that if savings can be done out of the existing money (without increasing the aggregate money supply); then inflation will not occur at all.

In this paper, I will deal with all these diagnosis and remedies of the Austrian School of Economics. After the introduction, there will discussions on how money has originated as commodity money; then how the money began to be created through embezzlement and fraudulence; then how the central bank emerged and began to create fiat money fraudulently. Thereafter, I will assess some observations on the present money and monetary system made by the Austrian School. These areas are fractional reserve banking, boom-bust cycle theory, optimum quantity of money, abolition of central bank. In the conclusion, I will suggest that much thought should be given to formulate such a system which will enable us to have such a money production system that will be costless yet it will carry value as if it is a commodity. Otherwise, there will be no end of the debate between the theories of commodity money and debt money. As finding a correct definition of money can solve all the economic problems; so it is the primary responsibility of the economists to fund out or construct such a theory that can eliminate limitations of both the commodity money and the debt money. 


\section{Changes in the forms and character of money from ancient to modern times.}

[Before we actually begin to assess whether commodity-money can serve the purpose of its use in economics sufficiently or not, we should have an understanding how the forms and character of money has been changed over the ages.]

\section{A. Origin of money as commodity-money}

Various theories regarding the origin of money have been put forward by different economists and schools. While the Orthodox Economists explain that various commodities had been used as medium of exchange in various countries in various times, the Heterodox Economists put forward different theories on the origins of money. Some of them suggest that money originated as a social understanding, some suggest money originated as debt or as a claim on others, some opine that money originated at the behest of the state. However, economists of the Austrian School have rightly upheld the Orthodox view of commodity-money. They argue that "Money did not and never could begin by some arbitrary social contract, or by some government agency decreeing that everyone has to accept the tickets it issues. Even coercion could not force people and institutions to accept meaningless tickets that they had not heard of or that bore no relation to any other pre-existing money. Money arises on the free market, as individuals on the market try to facilitate the vital process of exchange.". Initially the exchange of commodities started between two individuals. "But this system of "direct exchange" of useful goods, or "barter," has severe limitations which exchangers soon run up against. ... What he will have to do is to engage in "indirect exchange," that is, to sell the tractor for a more divisible commodity, say 100 pounds of butter, and then slice the butter into divisible parts and exchange each part for the good he desires. Robbins, again, would then be using butter as a medium of exchange. ... Once any particular commodity starts to be used as a medium, this very process has a spiraling, or snowballing, effect. If, for example, several people in a society begin to use butter as a medium, people will realize that in that particular region butter is becoming especially marketable, or acceptable in exchange, and so they will demand more butter in exchange for use as a medium. And so, as its use as a medium becomes more widely known, this use feeds upon itself, until rapidly the commodity comes into general employment in the society as a medium of exchange. A commodity that is in general use as a medium is defined as a money. ... Once a good comes into use as a money, the market expands rapidly, and the economy becomes remarkably more productive and prosperous. ... In the history of mankind, every society, including primitive tribes, rapidly developed money in the above manner, on the market. Many commodities have been used as money: iron hoes in Africa, salt in West Africa, sugar in the Caribbean, beaver skins in Canada, codfish in colonial New England, tobacco in colonial Maryland and Virginia. In German prisoner-of-war camps of British soldiers during World War II, the continuing trading of CARE packages soon 
resulted in a "money" in which all other goods were priced and reckoned. Cigarettes became the money in these camps, not because of any imposition by German or British officers or from any sudden agreement: it emerged "organically" from barter trading in spontaneously developed markets within the camps. Throughout all these eras and societies, however, two commodities, if the society had access to them, were easily able to outcompete the rest, and to establish themselves on the market as the only moneys. These were gold and silver." [Rothbard 2007, P 12-16].

\section{B.Development of embezzlement and fraudulence in money creation}

The banks of the olden days used to fraudulently create and increase their money. Rothbard explains how the past banks used to issue fraudulent money or embezzle the money deposited by the bank-customers in those banks. As "Gold coins are often heavy, difficult to carry around, and subject to risk of loss or theft. People began to "deposit" coins, as well as gold or silver bullion, into institutions for safekeeping. This function may be thought of as a "money-warehouse." As in the case of any other warehouse, the warehouse issues the depositor a receipt, a paper ticket pledging that the article will be redeemed at any time "on demand," that is, on presentation of the receipt." [Rothbard 2007, P 33-34]. "...people tend to leave their goods in the Trustee Warehouse for a considerable length of time and, in the case of goods that they do not use frequently, will even tend to transfer the goods-certificates (the warehouse receipts, or evidences of ownership of the goods) and not redeem the goods themselves. Thus, the goods certificates act as goods-substitutes in exchange. Suppose that the Trustee Company sees this happening. It realizes that a good opportunity for fraud presents itself." [Rothbard 2004, P 801-802]. "The banker can engage in two kinds of fraud and embezzlement. He may, for example, simply take the gold or cash out of the vault and live it up, spending money on mansions or yachts. However, this may be a dangerous procedure; if he should ever be caught out, and people demand their money, the embezzling nature of his act might strike everyone as crystal-clear. Instead, a far more sophisticated and less blatant course will be for him to issue warehouse receipts to money, warehouse receipts backed by nothing but looking identical to the genuine receipts, and to lend them out to borrowers. In short, the banker counterfeits warehouse receipts to money, and lends them out. In that way, insofar as the counterfeiter is neither detected nor challenged to redeem in actual cash, the new fake receipts will, like the old genuine ones, circulate on the market as if they were money." [Rothbard 2007, P 39-40]. "It should be clear that this practice is outright fraud. Someone else's property is taken by the warehouse and used for its own money-making purposes. It is not borrowed, since no interest is paid for the use of the money. Or, if spurious warehouse receipts are printed, evidences of goods are issued and sold or loaned without any such goods being in existence." [Rothbard 2004, P 802]. "It is, in fact, difficult to see the economic or moral difference between the issuance of pseudo receipts and the appropriation of someone 
else's property or outright embezzlement or, more directly, counterfeiting." [Rothbard 2004, P 803].

Before the establishment of modern central bank, there were many banks in a country. These banks generally used to commit such fraudulent practices. Due to their excessive creation of money that was not backed by gold or silver many bank-runs would cause many banks' failure.

\section{C.Combination of debt cum fraudulent money developed with the development of the central bank}

As counterfeiting, fraudulence and embezzlement to create money became rampant and bank-runs became widespread it became impossible for customers (including the government) and government became increasingly dependent on more and more bank loans, government decided to set up a central bank that would have the sole right to issue bank-notes and other banks would take bank-notes as loan from the central bank and would act as simple intermediaries between the depositor and lender. As government needed more money than it could offer as deposit to the bank in exchange for money, government allowed the central bank to create more money that would not be backed by any reserve. Thus, the central bank was empowered to create money against also the government-debt (other deposits were initial reserve of government deposits including gold and silver) whenever it needed to do so.

"It is significant that the Bank of England was launched to help the English government finance a large deficit. Governments everywhere and at all times are short of money, and much more desperately so than individuals or business firms." Rothbard 2007, [P 58] "Opening in July 1694, the Bank of England quickly issued the enormous sum of $£ 760,000$, most of which was used to purchase government debt. In less than two years time, the bank's outstanding notes of $£ 765,000$ were only backed by $£ 36,000$ in cash. A run demanding specie smashed the bank ... Specie payments resumed two years later, but from then on, the government allowed the Bank of England to suspend specie payment, while continuing in operation, every time it got into financial difficulties." [Rothbard 2007, P 60] "In 1697, the Bank of England induced Parliament to prohibit any new corporate bank from being established in England. In other words, no other incorporated bank could enter into competition with the Bank. In addition, counterfeiting Bank of England notes was now made punishable by death. A decade later, the government moved to grant the Bank of England a virtual monopoly on the issue of bank notes. In particular, after 1708, it was unlawful for any corporation other than the Bank of England to issue paper money, [Rothbard 2007, P 60-61] "The Bank of England was granted an absolute monopoly on the issue of all bank notes in England. These notes, in turn, were redeemable in gold. Private commercial banks were only allowed to issue demand deposits. This meant that, in order to acquire cash demanded by the public, the banks had to keep checking accounts at the Bank of England. In effect, bank demand 
deposits were redeemable in Bank of England notes, which in turn were redeemable in gold." [Rothbard 2007, P 61] Thus, all the central banks were set up in different countries with the same authority to fraudulently create money against the government bonds that they have already bought.

Though one of main objective of emergence of the central bank was "to help finance the government's deficit" by buying government securities directly yet nowadays central buys government bonds from the market. Initially after buying the government debt with its existing money the central bank again prints money against those government bonds keeping those bonds in its money issue department to match the balance of assets against the money issued by the money issue department. However, nowadays, central bank does not buy government bonds from the government directly. The government sells securities in the market. Later, for controlling the supply of money in the market through injecting or withdrawing money from the market, the central bank buys government securities either buys from or sells into the market. After buying government bonds from the market, the central bank keeps those bonds in its banking department. Whenever the central bank needs to create money to be able to give loans to the corporate and other borrowers, the central bank transfers those bonds to its Money Issue Department and creates money against those securities. However, it is to be noted that the central bank has bought those bonds with its existing money. Government bond is an agreement of loan on the part of the government. Though these bonds may be treated as assets of the banking department of the central bank, yet those cannot be treated as assets of the Money Issue Department for issuing money against those bands. Thus, with the setting up of central bank money became fiat i.e. un-backed money or fraudulent money.

\section{Review of some observations, on money and monetary policy, made by the Austrian School of Economics}

It is pertinent to assess some of the assertions of the Austrian School of Economics to have an understanding of this School's observation regarding money.

\section{A.Fractional reserve banking cum circulation credit}

This School is of the opinion that the banks create some kind of money that is not created by the central bank. This School opines that the banks create those unbacked money through fractional reserve banking. Rothbard makes a distinction between $100 \%$ reserve banking and fractional reserve banking giving two examples of how fractional reserve banking is done by the banks;

One type of reserve banking is when banks create more money than its reserve can support. Rothbard argues, "Suppose now that banks yield to the temptation to create fake warehouse receipts to cash, and lend these fake receipts out. What happens now is that the previously strictly separate functions of loan and deposit banking become muddled; 
the deposit trust is violated, and the deposit contract cannot be fulfilled if all the "creditors" try to redeem their claims. The phony warehouse receipts are loaned out by the bank. Fractional-reserve banking has reared its ugly head.

Thus, suppose that the Rothbard Deposit Bank in the previous table decides to create $\$ 15,000$ in fake warehouse receipts, unbacked by cash, but redeemable on demand in cash, and lends them out in various loans or purchases of securities. For how the Rothbard Bank's balance sheet now looks see Figure 5:

\begin{tabular}{|c|c|}
\hline \multicolumn{2}{|c|}{ Figure 5 } \\
Fractional-Reserve Banking \\
\hline \multicolumn{2}{|c|}{ Rothbard Deposit Bank } \\
\hline Assets & Equity + Liabilities \\
\hline $\begin{array}{c}\text { Cash: } \$ 20,000 \\
\text { IOUs from Debtors: } \$ 15,000\end{array}$ \\
\hline Total: $\$ 35,000$ & Warehouse Receipts to Cash: $\$ 35,000$ \\
\hline
\end{tabular}

In this case, something very different has happened in a bank's lending operation. ... The money supply has increased because warehouse receipts have been issued that are redeemable in cash but not fully backed by cash." [Rothbard 2007, P 48-49] Thus, according to Rothbard, banks can increase their unbacked money to any unlimited number.

Rothbard gives an example of a second type of fractional reserve banking. He argues, "Suppose that the Fed decides it wishes to expand the nation's total money supply by $\$ 10$ billion. If the money multiplier is 10 , then the Fed will choose to purchase $\$ 1$ billion of assets, generally U.S. government securities, on the open market. ... Note that the immediate result of the Fed's purchase of a $\$ 1$ billion government bond in the open market is to increase the nation's total money supply by $\$ 1$ billion. But this is only the first, immediate step. Because we live under a system of fractional-reserve banking, other consequences quickly ensue. There are now $\$ 1$ billion more in reserves in the banking system, and as a result, the banking system expands its money and credit, the expansion beginning with Chase and quickly spreading out to other banks in the financial system. In a brief period of time, about a couple of weeks, the entire banking system will have expanded credit and the money supply another $\$ 9$ billion, up to an increased money stock of $\$ 10$ billion. ... Figure 11, then, shows the consequences of the Fed purchase of $\$ 1$ billion of government bonds after a few weeks. 
Figure 11

Fed Buys a $\$ 1$ Billion Bond:

Result After a Few Weeks

\begin{tabular}{|c|c|}
\hline \multicolumn{2}{|c|}{ Commercial Banks } \\
\hline Assets & Equity + Liabilities \\
\hline $\begin{array}{c}\text { Loans and securities: }+\$ 9 \text { billion } \\
\text { Deposits at Fed } \\
\text { (Reserves): }+\$ 1 \text { billion }\end{array}$ & Demand deposits: $+\$ 10$ billion \\
\hline
\end{tabular}

\begin{tabular}{|c|c|}
\hline \multicolumn{2}{|c|}{ The Federal Reserve } \\
\hline Assets & Equity + Liabilities \\
\hline U.S. Government & Demand deposits to banks: \\
Securities: $+\$ 1$ billion & $+\$$ billion \\
\hline
\end{tabular}

... The change in totals has taken place among the commercial banks, who (143) have pyramided credits and deposits on top of their initial burst of reserves, to increase the nation's total money supply by $\$ 10$ billion." [Rothbard 2007, P 140-142]

\section{Assessment of Fractional reserve banking cum circulation of credit}

It should be noted here that though the banks of the past could embezzle the deposit of their customers and could create more money than their commodity (gold and silver) could support, nowadays banks cannot do that; because banks are prohibited to create any money. Nowadays, banks are intermediaries between the depositors or lenders (individuals, other banks, corporate, governments and even the central bank) and the borrowers (individuals, other banks, corporate, governments and even the central bank). Therefore, Rothbard's first example of creation of $\$ 15000$ more dollars is not correct. Banks cannot create any money; they just borrow and lend. "In each country its governmental "Central Bank" (in the United States, the Federal Reserve) is the sole monopoly source and creator of all money". [Rothbard 2007, P 11]

The second type of fractional reserve banking, i.e. creation of $\$ 9$ billion over a deposit of $\$ 1$ billion by the central bank, is not also possible. Because the money ( $\$ 9$ billion) that is supposed to be created through fractional reserve banking is not created at all; what is created is "open book account" or "checkable account". If any person issues a check on this account, he cannot use equal amount of money from his "checkable account". It is misleading that banks can increase initial deposit through the practice of fractional reserve banking. Rothbard himself accepts that money and the checkable account are not the same. He writes, "This transfer order has come to be known as a "check," and the open book deposit account at the bank as a "demand deposit," or "checking account."” 
[Rothbard 2007, P 55] "But even though the bank note and the demand deposit are economically equivalent, the two forms will not be equally marketable or acceptable on the market. The reason is that while a merchant or another bank must always trust the bank in question in order to accept its note, for a check to be accepted the receiver must trust not only the bank but also the person who signs the check." [Rothbard 2007, P 57]

Rothbard himself gives an example by lending the deposit bank does not fraudulently create money. Rothbard argues, "'Most people, however, think of "banks" as borrowing money from one set of people, and relending their money to another set, charging an interest differential because of its expertise in lending, in channeling capital to productive businesses. How would this sort of borrow-and lend bank operate?

Let us take the Rothbard Loan Bank, as shown in Figure 3, and assume that the Bank borrows money from the public in the form of Certificates of Deposit (CDs), repayable in six months or a year. Then, abstracting from the interest involved, and assuming the Rothbard Bank floats $\$ 40,000$ of CDs, and relends them, we will get a balance sheet as follows:

\begin{tabular}{|c|c|}
\hline \multicolumn{2}{|c|}{ The Loan Bank Borrows Money } \\
\hline \multicolumn{2}{|c|}{3} \\
\hline Assets & Equity + Liabilities \\
\hline Cash: $\$ 1,000$ & Owed in CDs: $\$ 40,000$ \\
IOUs: $\$ 49,500$ & Owned by Rothbard: $\$ 10,500$ \\
\hline Total: $\$ 50,500$ & Total: $\$ 50,500$ \\
\hline
\end{tabular}

Again, the important point is that the bank has grown, has borrowed and reloaned, and there has been no inflationary creation of new money, no fraudulent activity, and no counterfeiting. If the Rothbard Bank makes a bad loan, and becomes insolvent, then that is a normal entrepreneurial error. So far, loan banking has been a perfectly legitimate and productive activity." [Rothbard 2007, P 32-33]

Thus, banks are merely function as intermediaries and "Financial intermediation was useful because it prevented that savings remained dormant in idle money hoards". [Hulsmann 2015]

\section{B.Boom and Bust cycle}

Economists of the Austrian School view that money creation through fractional reserve banking is sole cause of boom-bust cycle. Rothbard argues, "In the case of bank money [created out of fractional reserve banking] ... the effect of the banker's depredations will not only be price inflation and redistribution of money and income, but also ruinous cycles of boom and bust generated by expansions and contractions of the counterfeit bank credit." [Rothbard 2007, P 40] He writes elsewhere, "We have so far emphasized that 
bank credit expansion under fractional-reserve banking (or "creation of counterfeit warehouse receipts") creates price inflation, loss of purchasing power of the currency unit, and redistribution of wealth and income. Euphoria caused by a pouring of new money into the economy is followed by grumbling as price inflation sets in, and some people benefit while others lose. But inflationary booms are not the only consequence of fractional-reserve counterfeiting. For at some point in the process, a reaction sets in. An actual bank run might set in, sweeping across the banking system; or banks, in fear of such a run, might suddenly contract their credit, call in and not renew their loans, and sell securities they own, in order to stay solvent. This sudden contraction will also swiftly contract the amount of warehouse receipts, or money, in circulation. In short, as the fractional-reserve system is either found out or in danger of being found out, swift credit contraction leads to a financial and business crisis and recession. There is no space here to go into a full analysis of business cycles, but it is clear that the credit-creation process by the banks habitually generates destructive boom-bust cycles." [Rothbard 2007, P 5455] Rothbard explains, "Mises' view, in contrast, is very different. He demonstrates that change in the money supply has important non-neutral effects on the "real" economy, in both short run and long. Money enters the system, not by helicopters showering an equiproportional increase on one and all, but at specific nodal points in the economy. An increase in paper money or bank credit, for example, will first increase the cash balances of government or bank, and then ripple out, in step-by-step micro fashion, from one set of cash balances to another, from government to defense contractor or from bank to debtor. In doing so, the distribution of money assets and incomes, as well as relative prices, will change permanently, in long run as well as short. In addition, some of the "short-run" effects will have dire economic consequences even if temporary, particularly the intervention by bank credit expansion into market signals of saving and interest rates, leading inevitably to a Mises-Hayek business cycle. As a result, there can be no separation between micro and macro. None of this is understood by the monetarists." [Rothbard Undated, $P$ 182]

\section{Assessment of the theory of Boom-Bust Cycle}

It is argued in this theory that as banks create money fraudulently without keeping any reserve against the money the banks create, banks fail to pay the reserve that is supposed to remain in the custody of the banks (when no sufficient reserve is there to be able to pay $100 \%$ of the bank receipts. They argue, thus bank-run occurs. Banks fail to issue more loans and therefore economics activities face severe liquidity crunch. This causes boom-bust cycle.

However, their understanding is wrong. Banks do not issue bank-receipts against any supposed deposit by the depositor for safe-keeping. Depositors lend money to the banks and gets interest in return for the period the deposit is held with the bank. Banks give two types of interests. If the loan is given on floating term i.e. depositor may claim his deposit 
any time; then the interest rate is low; it is called savings bank interest. If the depositor lend money to the bank for a specific term; then the interest is high; it is called fixed deposit interest.

Therefore, banks borrow from the depositors (government, central bank, individual, corporate or other banks) at a certain percent of interest and lends at a higher interest. Thus, banks just play a role of intermediaries between lender and borrower. Therefore, bank cannot create any money; and therefore, question of creating unbacked money by the bank does not arise at all.

Therefore, the fractional reserve banking cannot be the cause of the boom-bust cycle. Therefore, it is pertinent to search anew what is the real cause of boom-bust cycle.

\section{C. What Is the Optimum Quantity of Money?}

Rothbard opines that as money is primarily meant for facilitating exchange of commodities that is consumed and as money is not meant for consumption; therefore, the increase in quantity of money will not serve any useful purposes of the economy. Therefore he suggest that "once a money has been established in the market, no increase in its supply are needed" [Rothbard 2007, P 18]. Now, let us look how he explains his argument. Rothbard explains, "The total stock, or "supply," or quantity of money in any area or society at any given time is simply the sum total of all the ounces of gold, or units of money, in that particular society or region. Economists have often been concerned with the question: what is the "optimal" quantity of money, what should the total money stock be, at the present time? How fast should that total "grow"? ... In fact, the very question is absurd. ... It is because people sense the absurdity of such a question that it is virtually never raised." [Rothbard 2007, P 18]

He continues, "But of what direct benefit is an increase in the supply of money? Money, after all, can neither be eaten nor used up in production. The money-commodity, functioning as money, can only be used in exchange, in facilitating the transfer of goods and services, and in making economic calculation possible. But once a money has been established in the market,_no increases in its supply are needed, and they perform_no genuine social function. As we know from general economic theory, the invariable result of an increase in the supply of a good is to lower its price. For all products except money, such an increase is socially beneficial, since it means that production and living standards have increased in response to consumer demand. If steel or bread or houses are more plentiful and cheaper than before, everyone's standard of living benefits. But an increase in the supply of money cannot relieve the natural scarcity of consumer or capital goods; all it does is to make the dollar or the franc cheaper, that is, lower its purchasing power in terms of all other goods and services. Once a good has been established as money on the market, then, it exerts its full power as a mechanism of exchange or an instrument of calculation. All that an increase in the quantity of dollars can do is to dilute the 
effectiveness, the purchasing-power, of each dollar. Hence, the great truth of monetary theory emerges: once a commodity is in sufficient supply to be adopted as a money, no further increase in the supply of money is needed. Any quantity of money in society is "optimal." Once a money is established, an increase in its supply confers no social benefit. [Rothbard 2007, P 19-20] "Any rate of growth can therefore be accommodated by virtually any supply of natural monies such as gold and silver." [Hulsman 2008, P 61]

"Does that mean that, once gold became money, all mining and production of gold was a waste? No, because a greater supply of gold allowed an increase in gold's nonmonetary use: more abundant and lower-priced jewelry, ornaments, fillings for teeth, etc. But more gold as money was not needed in the economy. Money, then, is unique among goods and services since increases in its supply are neither beneficial nor needed; indeed, such increases only dilute money's unique value: to be a worthy object of exchange." [Rothbard 2007, P 20]

\section{Assessment of the Optimum Quantity of Money}

Rothbard did not say that increase of supply of gold is not necessary. What he says is "a greater supply of gold allowed an increase in gold's nonmonetary use: more abundant and lower-priced jewelry, ornaments, fillings for teeth, etc. But more gold as money was not needed in the economy". [Rothbard 2007, P 20]

It should be noted here that increase of gold as money is also a necessity. Because production of more goods will lead to increase demand of gold-money to facilitate the exchange of these more goods in the market, to keep intact the prices of other commodities. Rothbard himself accepts that otherwise, "the increased annual production of goods will more than offset the gradual increase in the money stock. The result will be a gradual fall in the price level, an increase in the purchasing power of the currency unit or gold ounce year after year". This means that if volume or amount of gold money is not increased corresponding to the increase of productions, the purchasing power of the gold will increase and the purchasing power of commodities will continue to decrease year after year. In course of time small exchanges will become impossible as gold could not be divided in such units with which the exchanges can be met. On the other hand, banks will be profited by increasing the value or price of their gold-reserve for readjusting the price of gold with the increase of production exchange of which will have to be adjusted with the same quantity of gold-money. Therefore, to keep pace with the increased production, gold-money has to be increased accordingly.

Though it is correct that money must be some kind of commodity that has its own intrinsic value, yet metal-money or gold-money poses serious problem to the economy. Every exchange of commodity needs a matching value of gold-money. Then, it implies that in a total volume of exchanges, half must be commodity and other half must be gold-money or commodity-money. It also implies that half of the labor is needed to produce a commodity 
and other half of labor is needed to produce gold-money or commodity-money for facilitating the exchange of that commodity. With the increase of production of consumer goods, production of gold-money or commodity money becomes necessary. Therefore, half of the labor-force will be wasted only to produce commodity-money "they perform no genuine social function " [Rothbard 2007, P 19].

Besides, gold cannot be produced artificially; it has to be mined. Gold mines may not have sufficient gold to meet the increasing demand for gold money. Even if other metal are also used as money, it is certain that one half of the labor force is needed to produce the metal-money that is sufficient for exchanging the commodity produced by other half of the labor-force. Therefore, use of metal-money or specifically gold-money poses serious problem of wastage of half of the available labor force for producing the commoditymoney. Therefore, more thoughts are needed to escape a serious problem like this.

The debt-money or fiat-money that is now in vogue, eliminates this problem of wastage of labor force for creation or production of money, because the money that is being created by the central bank is either paper-money or electronic-money that has no intrinsic value of its own. The production of such money entails little or no loss of labor. All the laborforce can be used for production of consumer goods.

However, though the present form of fiat-money does not need to waste any labor, yet it has also some serious defects. The Central bank creates money out of government debt (though it is a fraudulence to create money which is mere an agreement of loan and for which money has been paid by the central bank when it buys the government bond); therefore, it means central bank creates money out of nothing; the money is a fiat-money. It entails no cost, no labor, no reserve. However, the very process of injecting the money by the central bank is harmful to the economy.

Austrian economists themselves are aware of these limitations of gold-money. Hulsmann writes, "The qualification "virtually" takes account of the fact that there are certain technological limitations on the use of the precious metals. Suppose there are high growth rates over an extended period of time. In this case, it might be necessary to reduce coin sizes to such an extent that producing and using these coins becomes unpractical. This problem is very real in the case of gold. It has never existed in the case of silver- which is also why many informed writers consider silver to be the money par excellence. In any case, such technological problems pose no problem. As Bishop Oresme explained more than 700 years ago, the thing to do in such cases is simply to abandon the use of the unpractical coins, say gold coins, and switch to another precious metal, say silver. And, we may add, on the free market there are strong incentives to bring about such switching promptly and efficiently. No political intervention is necessary to support this process." [Hulsmann 2008, P 61] 


\section{D. What Can Be Done?}

\section{Abolish the Federal Reserve i.e. the Central Bank?}

According to Rothbard, the Federal Reserve "has wrecked our savings, distorted our currency, levied hidden redistribution of income and wealth, and brought us devastating booms and busts. ... The American economy has suffered from chronic inflation, and from destructive booms and busts, because that inflation has been invariably generated by the Fed itself. ... the very purpose of its existence [of Fed is] to cartelize the private commercial banks, and to help them inflate money and credit together, pumping in reserves to the banks, and bailing them out if they get into trouble. [Rothbard 2007, P 145]

"There is only one way to eliminate chronic inflation, as well as the booms and busts brought by that system of inflationary credit: and that is to eliminate the counterfeiting that constitutes and creates that inflation. And the only way to do that is to abolish legalized counterfeiting: that is, to abolish the Federal Reserve System, and return to the gold standard, to a monetary system where a market-produced metal, such as gold, serves as the standard money, and not paper tickets printed by the Federal Reserve. ... It would be easy to return to gold and to abolish the Federal Reserve, and to do so at one stroke. All we need is the will. The Federal Reserve is officially a "corporation," and the way to abolish it is the way any corporation, certainly any inherently insolvent corporation such as the Fed, is abolished." [Rothbard 2007, P 146]

Rothbard suggested that the outstanding government debt of $\$ 345$ billion as of April 6 , 1994, to the Fed should be cancelled. "This act would immediately reduce the taxpayers' liability for the public debt by $\$ 345$ billion. And indeed, why in the world should taxpayers be taxed by the U.S. Treasury in order to pay interest and principal on bonds held by another arm of the federal government-the Federal Reserve? The taxpayers have to be sweated and looted, merely to preserve the accounting fiction that the Fed is a corporation independent of the federal government. ... "Other Fed Assets," whether they be loans to banks, or buildings owned by the Fed, can be scrapped as well, although perhaps some of the assets can be salvaged. Treasury currency, simply old paper money issued by the Treasury, should quickly be canceled as well; and SDR's ( $\$ 8$ billion) were a hopeless experiment in world governmental paper that Keynesians had thought would form the basis of a new world fiat paper money. These two should be immediately canceled. ... \$6 billion are Treasury deposits with the Fed that should be canceled. That leaves the Federal Reserve with $\$ 11$ billion of gold stock to set off against $\$ 404$ billion in Fed liabilities." [Rothbard 2007, P 147-148]

This $\$ 11$ billion consists of 260 million ounces of gold; the price of gold being $\$ 42.22$ an ounce. 
"This has been an absurd undervaluation on its face, considering that the gold price on the world market has been varying from $\$ 350$ to $\$ 380$ an ounce in recent years. ... If we wish to revalue gold so that the 260 million gold ounces can pay off $\$ 404$ billion in Fed liabilities, then the new fixed value of gold should be set at $\$ 404$ billion divided by 260 million ounces, or $\$ 1555$ per gold ounce. If we revalue the Fed gold stock at the "price" of $\$ 1555$ per ounce, then its 260 million ounces will be worth $\$ 404$ billion. Or, to put it another way, the "dollar" would then be defined as 1/1555 of an ounce." [Rothbard 2007, $P$ 149]

"Once this revaluation takes place, the Fed could and should be liquidated, and its gold stock parcelled out; the Federal Reserve Notes could be called in and exchanged for gold coins minted by the Treasury. In the meanwhile, the banks' demand deposits at the Fed would be exchanged for gold bullion, which would then be located in the vaults of the banks, with the banks' deposits redeemable to its depositors in gold coin. In short, at one stroke, the Federal Reserve would be abolished, and the United States and its banks would then be back on the gold standard, with "dollars" redeemable in gold coin at $\$ 1555$ an ounce. Every bank would then stand, once again as before the Civil War, on its own bottom." [Rothbard 2007, P 149-150]

"One great advantage of this plan is its simplicity, as well as the minimal change in banking and the money supply that it would require. Even though the Fed would be abolished and the gold coin standard restored, there would, at this point, be no outlawry of fractional-reserve banking. The banks would therefore be left intact, but, with the Federal Reserve and its junior partner, federal deposit insurance, abolished, the banks would, at last, be on their own, each bank responsible for its own actions.44 There would be no lender of last resort, no taxpayer bailout. On the contrary, at the first sign of balking at redemption of any of its deposits in gold, any bank would be forced to close its doors immediately and liquidate its assets on behalf of its depositors. A gold-coin standard, coupled with instant liquidation for any bank that fails to meet its contractual obligations, would bring about a free banking system so "hard" and sound, that any problem of inflationary credit or counterfeiting would be minimal. It is perhaps a "second-best" solution to the ideal of treating fractional-reserve bankers as embezzlers, but it would suffice at least as an excellent solution for the time being, that is, until people are ready to press on to full 100 percent banking." [Rothbard 2007, P 150-151]

\section{Assessment of the plan of dissolving the central bank}

Some of the proposals of plan of abolishing the central bank is just and appropriate, while some proposals will create some problem. Cancellation of government debt is a wise decision. However, cancellation of SDRs ( $\$ 8$ million) will lead a loss of foreign commodity worth $\$ 8$ million to the country. However, overvaluing of gold ounces to $\$ 1555$ while the market value varies from $\$ 350$ to $\$ 380$, will create a serious problem. The gold producers, merchants, jewelers and individual holders of gold will be profited by $\$ 1555$ 
divided by $\$ 350$ or $\$ 380$ times. The Austrian School of Economics advocates that price of any commodity should be determined by the market forces of demand and supply. However, in this case they themselves are favoring arbitrary overvaluation of gold. While this proposal may well solve the dissolution of the central bank; it will enrich gold-holders disproportionately throughout the country and abroad.

Besides, what will the banks (now independent of any superior authority like the central bank) will do in face of constant increasing demand for money; because demand for money is always increasing due to increasing expansion of economic activities. Will they again overvalue their existing gold to meet the increasing demand for money? In that case, same thing will happen; banks will be profited at the cost of its clients (depositors and borrowers). The Austrian School is very much against this process; they feel justly that money should not be created fraudulently through embezzlement or counterfeiting or against nothing. The creation of more money against 4 fewer reserves is unethical and fraudulent; but same thing will be happened. The reserve of gold will remain as it is; the volume or amount of money will go on increasing. This is exactly what the banks are doing (According to the Austrian School) at present under fractional reserve banking; and what the Austrian School tries to eliminate by abolishing the central bank.

\section{Conclusion}

The Austrian School of Economics has correctly diagnosed that Money must be a commodity. "money would have no utility to hold in cash balance unless it had already enjoyed a previous existence and a purchasing power as money. ... Hence, the current value of money is fully explained, its historical dimension regressing logically until the money-commodity emerged out of barter, and, therefore, its last determinants are its supply and demand under barter. ... no money, and no money-unit, can ever emerge except through this process of beginning as a useful nonmonetary commodity in barter. Money must begin as a useful commodity in a market economy of barter. Otherwise, it could not have had a preexisting purchasing power so that people can evaluate and hold money. Unfortunately, once a commodity is established as money, paper or bank deposits can begin as representations of, and redeemable in, genuine commodity money". [Rothbard Undaed, $P$ 181] However, as we have seen in this discussion that commodity-money has severe limitation. At the same time debt-money or fiat money has also serious limitation.

Money is for facilitating the exchange between two commodities. It should not extinguish after any exchange. It should be used as a medium of exchange permanently. However, if money becomes a commodity-money; then some labor will be wasted to create the money. If somehow money could be created in such a way that it would cost little or nothing then the labor used for creating money will be utilized for creating socially useful or consumable commodities. Therefore, the suggestion will be to find out such a method so that money creation will be cost-less but it will have a commodityness i.e. it should 
carry the unit-value that is printed on it. Otherwise, there will be a constant debate on which of the debt-money and commodity-money is more appropriate to achieve a sustainable growth without being interrupted by occasional boom-bust cycle. This discussion followed the strict guideline set by the Call for Paper that reads, "Papers should be well developed, but at a stage where they can still benefit from the group's discussion".

\section{References}

Hulsmann, Jorg Guido 2008 -The Ethics of Money Production -Ludwig von Mises Institute

Hulsmann, Jorg Guido Feb. 2015 -Why the Austrian Understanding of Money and Banks Is So Important Mises Daily

Rothbard, Murray N. 2004-Man, Economy, and State, with Power and Market -Ludwig von Mises Institute

Rothbard Murray N. 2007 -The Case Against the Fed -Ludwig von Mises Institute

Rothbard, Murray N. Undated -Timberlake on the Austrian Theory of Money -A Comment -The Review of Austrian Economics

Polleit, Thorsten March 2012 -The Austrian School of Economics -An Introduction, Frankfurt

Spadaro, Louis M. 1978 -New Directions in Austrian Economics

Murray N. Rothbard. 2000 -America's Great Recession

Murray N. Rothbard Austrian Definitions of the Supply of Money, Polytechnic Institute of New York

Murphy, Robert P. Aug. 2010 -- Is Our Money Based on Debt?

Shostak, Frank -June 2017 -- Fractional-Reserve Banking and Money Creation

Shostak, Frank -Oct. 2018 -The Phillips Curve Myth

Murphy, Robert P., June 2014 -The Economics of the Great Depression -Mises Institute

Holcombe, Randall G. - April 2013 - How Economic Progress is Made - Mises

Mises, Ludwig von, June 2018 - Wages, Unemployment, and Inflation -Mises Wire

Roberts, T. J. -23 Aug. 2018 -Tax Evasion Is Not the Crime Taxation Is -Mises Institute

Hülsmann, Jörg Guido -19 Nov. 2018 -The Evolution of Mises' Monetary Thought -Mises Institute

Shostak, Frank -21 Nov.The Money Supply Is Never Too Small -Mises Wire

Murphy, Robert P., 01 Sept. 2016 - The Definition of Various Monetary Aggregation

Shostak, Frank -02 Jan. 2019 -Boom-Bust Cycles and Easy Money -Mises Wire

Barron, Patrick -21 Dec 2018 - The Monetary Base Never Returned -Mises Wire 